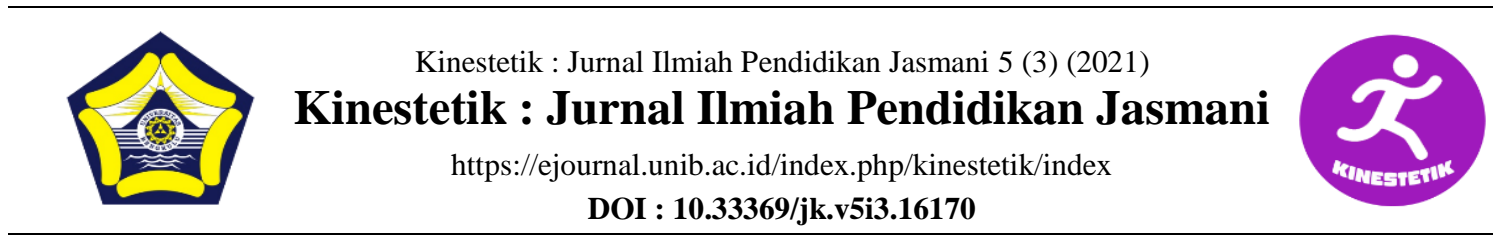

\title{
SOCIO-CULTURAL DEVELOPMENT IN JUDO ATHLETES
}

\author{
Berliana $^{1 *}$, Ira Purnamasari ${ }^{2}$, Geraldi Novian ${ }^{3}$ \\ ${ }^{12}$ Study Program of Sport Coaching Education, Faculty of Sport and Health Education, \\ Universitas Pendidikan Indonesia, Indonesia \\ ${ }^{2}$ Study Program of Sport Education, School of Postgraduate Studies, Universitas Pendidikan \\ Indonesia, Indonesia
}

\section{Article Info}

Article History :

Received : June 2021

Revised : September 2021

Accepted : September 2021

Available online : September 2021

\section{Keywords:}

Socio-Cultural, Discipline, Tolerance, Respect, Judo Athletes

\begin{abstract}
This study aims to develop the socio-culture of Judo athletes. Judo provides socio-cultural values to each individual involved through the training process that is carried out, these socio-cultural values are expected to remain in the daily life of Judo athletes. This study used an experimental method with a one-group pretest-posttest design research design. The treatment carried out during the experiment was an integration of socio-cultural value education with the Judo training process. Treatment is given for 6 weeks with a frequency of 2 sessions/week, each session consisting of 120 minutes divided into 5 parts, namely introduction, explanation, discussion, ice breaking, and closing. The sample used in this study was 10 athletes from Bandung PPLPD Judo by using a total sampling approach. The instrument that the author uses in this study is the TQR-Questionnaire which is given twice to the sample. The results showed that there was a significant influence between Judo training and the increase in social-cultural values of athletes. This indicates that Judo training can be included in instilling socio-cultural values, especially in Judo athletes.
\end{abstract}

\begin{tabular}{llr}
\hline Corresponding address & $:$ East Golf St. X Number 12, Bandung, & ISSN 2685-6514 (Online) \\
& West Java, Indonesia & ISSN 2477-331X (Print) \\
*Corresponding email & $:$ berliana@ upi.edu &
\end{tabular}




\section{INTRODUCTION}

The meaning of exercise is growing day by day, not only limited to physical activity. Many parties are starting to know and take advantage of the existence of sports, but some make sports seem like activities that are only carried out by athletes to achieve achievements. Sport coincides with the values of community and political institutions, as it seeks to define morals and ethics that are associated not only with athletes but also with the totality of society as a whole. Sport provides a key dynamic in terms of enhancing communal principles by enhancing individual physical and mental wellbeing and social class integration (Macri, 2012).

Sport is not only an activity to achieve achievement, but also an activity that can develop one's social and cultural values, even making the role of nationalism and viral motivation to boost socio-economic development (Thien \& Boonrod, 2019). Sport has the potential to contribute to social inclusion, foster and develop physical activities that improve health, forge an identity, and unite society. A wealth of research has considered how sport contributes to achieving wider social benefits, including improvements to health and well-being, life satisfaction, crime reduction, community cohesion and activism, environmental stewardship, educational attainment, labour market participation, civic renewal, urban regeneration and developing youth (Gilchrist \& Wheaton, 2017). Previous studies have suggested that sport plays an important socio-cultural role and this is also reflected in government policies designed to promote sport (Taylor et al., 2015).

Indonesia already has a good sports policy development, although it is still not as significant as European countries. Indonesia has recognized the benefits of sports that are so broad that they do not underestimate sports. Sport can be a medium for the development of human resources in various ways. As state by previous study, the benefits that can be obtained through sports include: reduce the increased risk of disease (such as coronary heart disease, hypertension, type-2 diabetes, cancer, metabolic syndrome, and all causes of death), improve quality of life, build self-confidence, improve symptom control, depression, and teach positive life values and values to young people (Andersen et al., 2019; Côté \& Hancock, 2016). It simply states that the outcome of sport for young people is the 3Ps: performance, participation, and personal development (Côté \& Hancock, 2016).

In this research, the writer specifically examines the socio-cultural development in Judo. Judo is a sport that is not only aimed at self-defense but more than that, namely namely the cultural aspects that surround sports practice (Peset et al., 2013). The philosophy of judo stipulates that in the face of an opponent, the safety of the opponent (uke) must be maintained, therefore when throwing an opponent, it cannot be released so that it remains 
controlled and does not injure or hurt the opponent as its main goal. In Judo, the goal of slamming an opponent is only one way to beat or win according to the competition rules that have been determined by the IJF (International Judo Federation) (Malliaropoulos et al., 2013).

As we know that almost all martial arts sports have their ways of interacting, such as giving special greetings to the coach, respect when entering the training ground, bowing to a higher level, clenching fists in front of the body before starting training/competitions, and others. Including in the sport of Judo, these things have become a culture that is directly applied in all social activities carried out. Judo provides socio-cultural values to each individual involved through a training process that is carried out as a form of life, which consists of behavior, skills, capacities, attitudes, values, beliefs, practices, and customs (Rothwell et al., 2018).

Especially for PPLPD Judo athletes who are coaching athletes who have been involved in the Judo training process intensively for quite a long time, so it is assumed that they already have existing socio-cultural values. The author wants to research related to the development of these socio-cultural values through an integrated educational process in the Judo training process. The author sees that this is still very rarely done in Indonesia, most studies only focus on physical conditions, achievement, or patterns of interaction between individuals. This is also in line with previous research which suggests that research related to sports and the socio-cultural domain is still very limited (Gemar, 2020), but was highlighted as an important area (Jaeschke et al., 2017). From here, it is hoped that they can become a constant in the daily life of Judo athletes. So this study aims to determine the development of sociocultural values in Judo athletes.

\section{METHODS}

The method used in this research is a quasi-experimental method with a quantitative approach. The research design used was the One-Group PretestPosttest Design, because this study only used one experimental group (Fraenkel et al., 2012).

\section{Participants}

The sample in this study was 10 PPLPD Judo athletes from the city of Bandung who were taken from the population using total sampling techniques. The reason for selecting the sample is because the athletes are still beginners and still have a long time to have a career as an elite athlete. Thus, it is hoped that it can become an example for other Judo athletes at a lower level.

\section{Materials and Apparatus}

The instrument that the author uses in this study is the DTRQuestionnaire which contains 60 items about discipline, tolerance, and respect. Filling in the instrument uses a Likert scale as an answer option (Mawardi, 
2019). The instrument is distributed via Google Form. The instrument was compiled by the author and has gone through the validity (0.723) and reliability test (0.812) stages so that it is suitable for use as a research instrument. The same instrument was given twice, namely at the pretest and posttest.

\section{Treatment}

The treatment that was applied during the experimental process was in the form of an exercise program with the integration of socio-cultural value education. During the experimentation, the entire program was observed for its continuity and the ability of the sample to absorb the program by the experts appointed in their fields. Treatment is given for 6 weeks with a frequency of 2 sessions/week, each session consisting of 120 minutes divided into 5 parts, namely introduction (15 minutes), explanation (50 minutes), discussion (30 minutes), ice-breaking (15 minutes) and closing (10 minutes).

\section{Data Analysis}

The data obtained were then processed and analyzed using SPSS version 24 (Santoso, 2017) in the following order: demographic data description, research description, normality test using the One-Sample Kolmogorov-Smirnov Test, and hypothesis testing using the Paired Sample Test.

\section{RESULT}

The data that has been processed and analyzed is then presented in tabular form so that it is easier to understand. It is known that the study sample consisted of $40 \%$ male athletes and $60 \%$ female athletes $(n=10)$. The age category of male athletes is $75 \%$ early adolescence (12-16 years) and 25\% late adolescence (17-25 years), while the age category of female athletes is $83 \%$ early adolescents (12-16 years) and $17 \%$ adolescents end (17-25 years). The education level of male athletes is $25 \%$ junior high school and $75 \%$ senior high school, while the education level of female athletes is $50 \%$ junior high school and 50\% senior high school.

Table 1. Statistical Descriptive

\begin{tabular}{ccc}
\hline & N & Mean \pm SD \\
\hline Pretest & 10 & $413.50 \pm 22.965$ \\
\hline Posttest & 10 & $448.60 \pm 38.962$ \\
\hline Gain & 10 & $35.10 \pm 15.997$ \\
\hline
\end{tabular}

Table 1 shows a description of the socio-cultural statistics. Obtained an average pretest value of 413.50 with a standard deviation of 22,965 and an average posttest value of 448.60 with a standard deviation of 38,962 .

Tabel 2. Normality Testing

\begin{tabular}{cc}
\hline & Asymp Sig. (2-tailed) \\
\hline Pretest & 0,200 \\
\hline Posttest & 0,060 \\
\hline
\end{tabular}


Table 2 shows the results of the normality test using the KolmogorovSmirnov Test. Asymp Sig. (2-tailed) value for the pretest data of 0.200 and the posttest data of 0.060 . Both data are> 0.05 , which means that the data is normally distributed, so the authors use a parametric approach to test the hypothesis.

Tabel 3. Hypothesis Testing

\begin{tabular}{llll}
\hline Variabel & $t$ Score & df & Sig. (2-tailed) \\
\hline
\end{tabular}

\section{DISCUSSION}

The results of this study indicate that there is a significant influence between the integrated Judo training program with the education of sociocultural values on the socio-cultural development of Judo athletes. This shows that the treatment in the form of socio-cultural value education arranged in an integrated program with the Judo training process can develop sociocultural values in Judo athletes. In the context of athlete performance, this relates to the experiences, abilities, and capacities of individuals currently available that are captured in their intrinsic dynamics (dispositional tendencies) in a constraint-based framework (Rothwell et al., 2018). The literature generally supports the relationship between sport and positive psychological and social outcomes, including self-esteem, self-regulation, general life skills, and pro-social behavior (Clark et al., 2015). Life skills such as time management,

\begin{tabular}{cccc}
\hline $\begin{array}{c}\text { Socio- } \\
\text { Cultural }\end{array}$ & 4,062 & 9 & 0,003 \\
\hline
\end{tabular}

Table 3 shows the results of hypothesis testing using the Paired Sample Test. Obtained the $\mathrm{t}$ score is 4.062 with the Sig. (2-tailed) value is 0.003 . The research testing criteria is if $t$ score $>\mathrm{t}$ table, then $\mathrm{H}_{1}$ is rejected and $\mathrm{H}_{0}$ is accepted. At the 5\% significance level with df 9 , the t table value is 2.262 , it can be concluded that $\mathrm{t}$ score $>\mathrm{t}$ table, so $\mathrm{H}_{0}$ is

accepted.

communication, coping, goal setting, and decision making provide an important foundation for achieving successful developmental goals (for example, academic success) (Clark et al., 2015). We all know that the aim of Judo is more than just self-defense, which is to form human character and mentality and form the body to be strong, useful for health, and shape character through mental and discipline (Malliaropoulos et al., 2013).

The principles of Judo are seiryoku zen'yo (efficiency, maximum efficiency, and minimum effort) and jita kyoei (mutual welfare and benefit) which means that fighting the stronger will result in defeat while adjusting and avoiding the opponent's attacks will cause him to lose balance., his strength will decrease and will be able to beat him (Malliaropoulos et al., 2013). Judo must also contain elements of manners, beautiful art, big spirit, sportsmanship, and mutual respect. Judo which is a martial arts sport is associated with harsh techniques, such as slamming, locking, strangling, and breaking opponents, if 
used in the wrong way will result in violence, this is of course not in line with the philosophy of the sport of Judo, namely Seiryoku Zen, which explains that the use of Judo sports energy is only for good purposes. Therefore, socially and culturally, Judo should be done with good intentions, including making good human relations, helping each other, and respecting each other (Nobuo, 2013). If its application is in the form of obtaining knowledge, then Judo can be a method of improving oneself and changing behavior for the better, because behavior change is the most important factor which is expected to foster children's social behavior (Berliana \& Purnamasari, 2016).

The social interactions that occur in Judo make a judo a cultured creature. The form of sports activities carried out encourages a positive direction from commercialism, sexism, and most importantly, one's nationalism (Macri, 2012). As individual beings as well as socio-cultural beings, to achieve needs, humans must deal with other humans, so that they have interests with other humans. Humans must live together with other humans in a unit called society or the social environment. As a middle way to reduce the risk of conflict, shared values, norms, or rules called common ethics are raised. This common ethic is what has continuously become a common norm from generation to generation which eventually develops into a culture. Every human being lives in a different socio-cultural environment so that it will apply different socio- cultural values, adjusted to the residents who live in it. Through a continuous process, every human being will embrace a value obtained from his environment. These values are adopted and then implemented in a form of a "habit" pattern. The behavior pattern of a person in interacting with others will be influenced by the values obtained from the socio-cultural environment. Through Judo, Judo athletes can become human beings who have good socio-cultural values so that they can be kept away from conflicts and can resolve conflicts around their lives.

In particular, this study took three socio-cultural values, namely discipline, tolerance, and respect. The author sees that these three things are the main keys for a person in social life who can be developed through sports. As stated, neglecting sports means neglecting important aspects of society and culture (Macri, 2012). Affordability connotes the mutuality of athlete relationships embedded in life forms that will provide a strong rationale for considering socio-cultural and historical boundaries in the environment that shape expectations and beliefs about how athletes should behave, perform in competition, develop and learn (Rothwell et al., 2018). Discipline can be defined as a condition that is created and formed through a process and a series of behaviors that show order. Discipline is very important to instill in athletes so that athletes become aware that with discipline optimal training results will be achieved. Discipline can shape a person's 
character so that they become provisions in facing the social environment (Wouw \& Ani, 2016).

The coach's role in instilling discipline is very important for athletes because coaches often communicate intensively and athletes tend to obey the coach. However, coaches are often misunderstood and tend to focus on punishment, when in fact it is not like that. Discipline is not focused on the punishment that must be given to athletes, but how the coach can explain the actions that can be done and the rules that must be carried out by athletes as a process of shaping the athlete's sociocultural value. Discipline provides benefits for developing conscientious athletic self-control. Punishing or frightening athletes to break the prevailing rules is a function of discipline that is no longer beneficial to athletes today. Discipline is expected to create athletes who are moral, character, disciplined, and obedient to the rules or regulations to be able to create the next generation of the Indonesian nation.

The next socio-cultural value is tolerance. Tolerance can be interpreted as a stance or attitude that is manifested in the willingness to accept various views and positions even though they disagree with them. Tolerance can also be defined as attitudes and actions that respect differences in religion, ethnicity, ethnicity, opinions, attitudes, and actions of others who are different from themselves (A'la, 2019). Tolerance can also be called a part of patience, by showing a person's ability to endure even in the most difficult or most unpleasant situations. With an attitude of tolerance, it is hoped that individuals can coexist between existing differences. A person must not discriminate in the treatment of other people who have different levels of maturity and backgrounds from himself. A person must continue to accept and respect other people who have different backgrounds from himself. This value of tolerance can be seen from several aspects, namely peace, respect for differences, and awareness. In particular, the value of tolerance is very important for athletes because athletes in the training process do not only train themselves but with other people who of course have differences. The differences that exist can include such as family and economic background, individual attitudes and characteristics, as well as individual responses to something. If the athlete does not have a good tolerance value, the athlete will easily feel hurt or easily hurt others. So athletes need to have a tolerance value so that the athlete's socio-cultural life will be more harmonious and orderly.

The last socio-cultural value studied in this study is respect. Respect can be simply defined as respect for something. Respect will occur if there is a good relationship between one individual and another. Simply put, respect is reflected in how a person appreciates and respects oneself and others. If a person does not respect himself, then he is very unlikely to respect others. In athletes, respect makes athletes more positive because it starts 
with respect, reluctance, and respect. Athletes will always look at a stimulus well if he has a good value of respect. Through Judo, respect is strongly instilled by the Judo philosophy. Without respect, athletes will be difficult to appreciate and tend to be alienated in their daily lives. Thus, if athletes have good respect, then they will have a good socio-cultural relationship so that they can build healthy relationships between athletes and coaches as well as all teams who are members of the training and respect each other. The social, cultural, and historical context in which athletes develop increasingly functional relationships with performance contexts are important things that must be understood (Rothwell et al., 2018) and should not be ignored because they have a long impact on the life of positive youth development (Clark et al., 2015).

\section{CONCLUSION}

This study concludes that the socio-cultural value education arranged in an integrated program with the Judo training process can develop sociocultural values in Judo athletes. Coaches and administrators need to be more serious in instilling the socio-cultural values of athletes because this will be very beneficial for athletes in the future, especially for young athletes. This research is still limited to the sport of Judo, so the authors suggest carrying out related research in other sports because we all realize that sport has been proven to be a medium for socio-cultural development for individuals.

\section{ACKNOWLEDGEMENT}

The author would like to thank all research subjects who have been willing to be involved in this research.

\section{REFERENCES}

A'la, M. (2019). Penguatan Karakter Toleransi Melalui Permainan Tradisional Dalam Pembelajaran PJOK di Sekolah Dasar. MAGISTRA: Media Pengembangan Ilmu Pendidikan Dasar Dan Keislaman, $10(2), \quad 130$. https://doi.org/10.31942/mgs.v10i2. 3108

Andersen, M. H., Ottesen, L., \& Thing, L. F. (2019). The social and psychological health outcomes of team sport participation in adults: An integrative review of research. Scandinavian Journal of Public Health, 47(8), 832-850. https://doi.org/10.1177/1403494818 791405

Berliana, B., \& Purnamasari, I. (2016). Judging Social Behavior and Level of Intellegence Changes as A Result of Team Sport Training. Advances in Economics, Business and Management Research, 14, 388390. https://doi.org/10.2991/icemal16.2016.81

Clark, H. J., Camiré, M., Wade, T. J., \& Cairney, J. (2015). Sport participation and its association with social and psychological factors known to predict substance use and abuse among youth: A scoping review of the literature. International Review of Sport and Exercise Psychology, 8(1), 224-250. https://doi.org/10.1080/1750984X.2 015.1068829

Côté, J., \& Hancock, D. J. (2016). Evidence-based policies for youth 
sport programmes. International Journal of Sport Policy, 8(1), 51-65. https://doi.org/10.1080/19406940.20 14.919338

Fraenkel, J. R., Wallen, N. E., \& Hyun, H. H. (2012). How to Design and Evaluate Research in Education (8th Ed.). Mc Graw Hill.

Gemar, A. (2020). Sport as culture: Social class, styles of cultural consumption and sports participation in Canada. International Review for the Sociology of Sport, 55(2), 186-208. https://doi.org/10.1177/1012690218 793855

Gilchrist, P., \& Wheaton, B. (2017). The social benefits of informal and lifestyle sports: a research agenda. International Journal of Sport Policy, 9(1), 1-10. https://doi.org/10.1080/19406940.20 17.1293132

Jaeschke, L., Steinbrecher, A., Luzak, A., Puggina, A., Aleksovska, K., Buck, C., Burns, C., Cardon, G., Carlin, A., Chantal, S., Ciarapica, D., Condello, G., Coppinger, T., Cortis, C., De Craemer, M., D'Haese, S., Di Blasio, A., Hansen, S., Iacoviello, L., ... Volkert, D. (2017). Sociocultural determinants of physical activity across the life course: A 'Determinants of Diet and Physical Activity' (DEDIPAC) umbrella systematic literature review. International Journal of Behavioral Nutrition and Physical Activity, 14(1), 1-15. https://doi.org/10.1186/s12966-0170627-3

Macri, K. J. (2012). Not Just a Game: Sport and Society in the United States. In Inquiries Journal/Student Pulse (Vol. 4, Issue 08). http://www.inquiriesjournal.com/a?i $\mathrm{d}=1664$

Malliaropoulos, N., Callan, M., \& Pluim,
B. (2013). Judo, the gentle way. 47(18), 54260. https://doi.org/10.1136/bjsports2013-093161

Mawardi, M. (2019). The Direction Of The Likert Attitude Scale Formulation To Measure Student's Attitude. Scholaria: Jurnal Pendidikan Dan Kebudayaan, 9(3), 292-304.

https://doi.org/10.24246/j.js.2019.v9 .i3.p292-304

Nobuo, H. (2013). No Title. Journal of Health, Physical Education, Recreation, April, 37-41.

Peset, F., Ferrer-Sapena, A., Villamón, M., González, L. M., Toca-Herrera, J. L., \& Aleixandre-Benavent, R. (2013). Scientific literature analysis of judo in Web of Science. Archives of Budo, 9(2), 81-91. https://doi.org/10.12659/AOB.8838 83

Rothwell, M., Davids, K., \& Stone, J. (2018). Harnessing socio-cultural constraints on athlete development to create a form of life. Journal of Expertise, 10(10), 94-102.

Santoso, S. (2017). Complete Guide to Mastering Statistics with SPSS 24. PT. Elex Media Komputindo.

Taylor, P., Davies, L., Wells, P., Gilbertson, J., \& Tayleur, W. (2015). The Social Impact of Engagement with Culture and Sport (Issue March). The Culture and Sport Evidence (CASE) Programme. Thien, H. T., \& Boonrod, W. (2019). Socio-cultural impacts of professional football clubs on local residents: Developing and validation of measurement scale in Vietnam. Annals of Applied Sport Science, 7(4), 43-51. https://doi.org/10.29252/aassjournal. 787

Wouw, S., \& Ani, Y. (2016). Konsistensi strategi instruksional pendidikan 
Berliana et al / Kinestetik : Jurnal Ilmiah Pendidikan Jasmani 5 (3) (2021)

jasmani, olahraga dan kesehatan

( PJOK ). Polyglot: Journal of

Language, Literature, Cullture, and

Education, 12(2), 117-127. 